Arab World English Journal (AWEJ) Volume 12. Number2 June 2021

Pp.22 -30

DOI: https://dx.doi.org/10.24093/awej/vol12no2.2

\title{
English As Secondary Language Learning and Autism Spectrum Disorder: The Obstacles in Teaching and Learning the Language
}

\author{
Haida Umiera Hashim \\ Faculty of Education, Universiti Kebangsaan Malaysia \\ Corresponding Author: haidaumiera@gmail.com \\ Melor Md Yunus \\ Faculty of Education, Universiti Kebangsaan Malaysia \\ Helmi Norman \\ Faculty of Education, Universiti Kebangsaan Malaysia
}

Received: 3/25/2021

Accepted: 5/23/2021

Published: 6/24/2021

\begin{abstract}
To this date, there has been an increasing number of children across the globe diagnosed with an autism spectrum disorder. There has been much literature that discussed the issues and obstacles common learners face in their English language learning journey. Yet, not much spotlight and acknowledgment were given to the learners with Autism in their voyage of English language learning. In conjunction to that, this paper intends to investigate the obstacles that the learners with Autism face in their English as secondary language learning. In addition to that, teachers are not to be forgotten as teachers are also believed to be playing a role in learners with Autism's English as a second language(ESL) learning process which is why this research also intends to investigate the challenges faced by the teachers who are in charge of teaching learners with Autism. A qualitative research with the observation and interview as the instruments represents this research. This research involved two Autism Centres located in an urban area in Malaysia. The observation and interviews were conducted with forty-five learners with Autism and fourteen teachers. The findings have gathered that the world of Autism Spectrum Disorder is indeed full of obstacles and challenges but none that could not be overcome. It is believed that this research will provide a better insight of the real world of ESL teaching and learning among learners with Autism. Discussions and recommendations are further explained in this research. Keywords: Autism Spectrum Disorder, challenges, English as Secondary Language, language learning, obstacles
\end{abstract}

Cite as: Hashim,H. U., Yunus, M.M., Norman, H. (2021). English As Secondary Language Learning and Autism Spectrum Disorder: The Obstacles in Teaching and Learning the Language. Arab World English Journal, 12 (2) 22-30.

DOI: https://dx.doi.org/10.24093/awej/vol12no2.2 


\section{Introduction}

To date, an increasing number of children across the globe are diagnosed with Autism in which Autism Spectrum Disorder (ASD), according to Happe \& Frith (2020), causes a child to experience persistent problems in social communication and interactions across multiple contexts as well as show restricted, repetitive patterns of behavior, interests and activities. These symptoms can be categorized into mild and severe symptoms, where higher levels require more support in daily life (Koo, Gaul, Rivera, Pan \& Fong 2018). As we move towards UNESCO's sustainable development goals (in which number four lays emphasizes on inclusion of education via quality education), there is an urgent need for learning to be inclusive regardless of special needs, especially children with autism spectrum disorders (ASD) (UNESCO, 2017). Education Act (1996) has specifically defined that special education students are students with learning disabilities such as sight, hearing, speech, Down Syndrome, mild Autism, Attention Deficit Hyperactivity (ADHD), minimal mental disorder retardation and dyslexia. According to Salleh (2019), inclusion of children with disabilities has been increasing worldwide since the declaration on "Education for All" in Jomtien; Thailand in 1990 and in a conference in Salamanca; Spain on Special Needs Education.

Malaysia has taken the initiative to be one of the 164 signatory countries that affirmed "Education for All" and has included inclusion in the National Education Blueprint 2013-2025 as part of the effort to achieve caring Malaysian slogan in Vision 2020 (Salleh, 2019). The Malaysian Education Blueprint 2013-2025 ensure inclusivity which includes students with visual impairment, hearing impairment, speech difficulties, learning disabilities such as Autism, etc (Ministry Of Education (MOE), 2013; Khairuddin, Salleh \& Amin, 2020). Ministry of Education Malaysia has implemented "Zero Reject Policy", which requires schools to accept children with disabilities to ensure that no children with disabilities are to be left behind (Othman \& Rahmat, 2020). UNICEF, in its research on "Childhood Disability in Malaysia; A Study of Knowledge; Attitudes and Practices" in 2016 has gathered that practices of inclusion, however, are not widely accepted in Malaysia due to teachers' limited knowledge and skills in handling children with disabilities (Ramakrishnan, Salleh, \& Alias, 2020). In the global and local landscapes, a pressing issue has been illustrated, in which the underprivileged community, especially children with special needs, are left behind (Shin et al., 2020) When it comes to education, especially English language learning in Malaysian context, Teo, Lau and Then (2020) mentioned that both children on the spectrum and educators tend to face obstacles with their English language teaching and learning process. This paper intends to provide significance to the parties that are relevant to the education world which are the policymakers and also teachers. Learners with Autism are unique in their ways and they also go through the same learning journey as mainstream learners regardless of their unique condition. There have been many literatures that discussed the issues and obstacles faced by mainstream learners in their ESL learning. Yet, not much spotlight and acknowledgment are given to the learners with Autism in their voyage of English language learning.

In conjunction with that, this research aims to investigate the obstacles faced by 1 . The learners of Autism in their English as secondary language (ESL) learning process and 2. The teachers in teaching English as a secondary language (ESL) learning to the learners with Autism. The research is underpinned by two research questions; 1 . What are the challenges and obstacles 
learners with autism face with their ESL learning process and 2. What are the challenges and obstacles teachers usually encounter during their ESL teaching process?

\section{Literature Review \\ Autism Spectrum Disorder}

Autism Spectrum Disorder (ASD) or widely known in short as Autism, is a spectrum disorder identified by various of characteristics, which usually includes perceptual, cognitive, and social differences (Bosseler \& Massaro, 2003; American Psychiatric Association, 1996; Rahman et al., 2020). Khowaja et al., (2019) mentioned that American Psychiatric Association defined autism spectrum disorder as a neurological disorder which diagnosed child may face difficulty in social communication or have a repeated or restricted set of behaviors (Porters, Vieira, Souza, 2020; Hannan, Satari, Abu, \& Yunus, 2020). Among the significant characteristics, most of the children with Autism have limited ability to produce and comprehend spoken language. Autism is seen as a mental disability instead of a psychiatric illness, and children as autism learners usually require a particular education process instead of tools that can assist them in their basic social, communication and reasoning skills (Luneski, Konstanidis, Hitoglou-Antoniadou, \& Bamidis, 2008). According to Skewes, Kemp, Paton and Hohwy (2020), another trait of children with Autism is that they learn through repetitions and one of the ways for them to grasp the learning process is via repetitions.

Busby, Ingram, Bowron, Oliver and Lyons (2012) mentioned that it is crucial for both educators and teachers to feel competent in teaching children with Autism. In their research on addressing teacher challenges and preparation needs in teaching elementary children with Autism, they have discovered that many general educators frequently expressed their misgivings about teaching children with Autism. In some studies, it is shown that some teachers believe that teaching children with Autism should be the scope job of the special educators. This then leads to the teachers to feel incompetent in handling children with Autism. Busby et al., (2012) believed that adequate training should be provided to the teachers to help increase their sense of self-efficacy. When the teachers begin to feel competent in their abilities to teach children with Autism, they may be more motivated and engaged in their responsibilities of teaching these children.

According to Notbohm and Zysk (2006), Autism is a highly complex disorder and there is no way for us to generalize Autism or children with Autism. Each child will be at a different point of the spectrum and child or adult, each will have a unique set of needs (Hannan, Satari, Abu \& Yunus, 2020). Notbohm and Zysk (2006) indirectly stated some of the familiar characteristics and traits of children with Autism. Some of the traits are;

- Their sensory perceptions are disorder

- $\quad$ Receptive and expressive language and vocabulary can be massive challenges for them

- $\quad$ They are concrete thinkers which means they interpret language literally

- They have limited vocabulary. It is always hard for them to express what they feel

- $\quad$ They are very visually oriented. They learn best through pictures and also repetitions

- They usually encounter trouble with social interactions

- $\quad$ They will meltdown and throw tantrums which might have caused by overload senses 


\section{English for Autism and Its Importance}

Learning a language is a thorough process (Lord, Brugha, Charman, Cusack, Dumas, Frazier \& Taylor 2020; Dornyei, 2019) and for children at a preschool level, their process of language learning is just a starter. The starter for their language learning should not be taken lightly as it plays a significant role when they are about to develop their language learning through time. Both parents and teachers play in role in helping learners with Autism with their voyage of language learning (Chu, Mohd, Mc Connell, Tan \& Joginder, 2020). English language learning consists of a few mastery skills namely, reading; writing; speaking; listening; grammar and vocabulary. Both learners and educators sometimes tend to forget and ignore the importance of English vocabulary development.

English language is no longer a stranger now in today's era of globalization. In Malaysian context, ESL learning has to become a rising issue in the Malaysian Education System (Adan \& Hashim 2021). Majority now has gotten full awareness on the importance of English language (Symons \& Ponzio, 2019). English language is now the global language which is used by everyone all around the world. In most developed countries, even English language has become the second language that needs to be learned by the learners since preschool. Kaprva (2019) in her documentation research on the importance of English in the modern world has figured that English language functions as the medium for all aspects of living such as globalization, education, career, travel, culture and even in technologies. In the education field, English is now a language of education (Chandran \& Hashim 2021). Children will start to learn English language from preschool up until in their phase tertiary education level. The learning and acquisition of English language will provide them with a more significant opportunity for good education and a successful career.

One of the best ways learners with mild Autism can learn best is via images and pictures as according to Büyük, Nizam, Akgül and Çamurcu (2019), they are more attracted to images. The term related to children with Autism is "Social Stories". Ghanouni et al., (2018), in their research, mentioned that social stories play a role as a method of teaching that facilitate the understanding of the social context that a child might find difficult to interpret, which leads them to have a better learning process. Previous studies have shown that social stories can improve understanding social situations, inferring perspectives of others and demonstrating appropriate behavior. Satari, Yasin, Toran and Mohamed (2020) believed that early intervention is required as early as possible for learners with Autism as it is intended to help learners to master basic skills that are appropriate and suitable to the learners' needs.

\section{Methods}

This paper employed a qualitative design of research where observation with field notes and interviews are used as the instruments. The respondents for this research include forty-five learners of Autism and fourteen teachers teaching learners with Autism were involved. This research is conducted at two Autism centers in an urban area located in Selangor, Malaysia. The learners were in their preschool level of education with the mild condition of Autism with the range of age between 7-10 years old. The data collection procedures were conducted through observation using field notes as instrument to observe the learning environment of learners with Autism. The observation is conducted to observe what are the challenges faced by the learners in their ESL learning process. In addition to that, interviews are also conducted with the teachers 
who are in charge of teaching the learners with Autism. The interviews were conducted to get an insight into what the teachers usually face and encounter during their teaching process involving the learners with Autism. The interviews were conducted with the teachers who were teaching the learners with Autism at the centers. Both observation and interviews conducted were aimed to investigate the obstacles faced by both the learners and teachers in their English as secondary language learning and teaching process. The data collected from both observation and interviews were then analyzed thematically.

\section{Findings}

The data gathered in this research via observation and interviews were then later categorized and discussed thematically into two sub-themes of findings namely; 1 . The challenges faced by learners with mild Autism in their language learning journey and 2 . The challenges faced by the teachers concerning to their teaching process.

\section{The Challenges Faced by Learners with Mild Autism in their Language Learning Journey}

Based on the findings, it can be seen that learners with Autism commonly demonstrate difficulties in responding and initiating social interactions. They usually struggle to provide responses and interact with other people. Due to their cognitive disabilities, most learners with Autism struggle to acquire new vocabulary. Learners with Autism mostly tend to grasp English language faster than their mother tongue language. According to the Special Education field expert, learners with Autism will acquire English words and language more quickly due to the linguistic aspect of English language. In comparison to the other languages, English language is more straightforward and has less amount of syllables which makes it even easier for learners with Autism to grasp the language. Regardless, learners with Autism still encounter difficulties in learning and acquiring the language as the process is not a straightforward process for every learner. Every learner has their own styles of learning, also preferences in acquiring a language primarily English language. This applies the same to the learners with Autism. They also learn differently and each one of them differs in terms of learning styles and learning preferences.

The findings have also gathered that learning can be a very challenging process for children with Autism at their early childhood phase due to their cognitive disability. As children with Autism are primarily visual learners, one of the best ways they can learn best is via images and pictures. The term related to learners with Autism is "Social Stories". Social stories play a role as a method of teaching to help facilitate the understanding of the social context that a child might find difficult to interpret.

\section{The Challenges Faced by the Teachers in regard to their Teaching Process}

Teachers play a crucial role in teaching children with Autism. Due to the different behaviors and characteristics of Autism learners, the findings have gathered that some teachers struggle in trying to personalize the teaching and learning materials depending on the learner's preferences. Sometimes, due to time constraint and teachers shortage, teachers in charge need to be able to try to adapt and adopt the materials depending on the learners' preferences. Teachers also sometimes need to customize their own materials in order to get the learners' motivation and attention to learn. The findings have figured out that teachers face this issue as they find it tiring to keep on repeating the teaching and learning process every day. The tear and wear condition of 
the hardcopy teaching aids handmade by the teachers are to be regarded as not one of the best teaching and learning aids for learners with Autism.

\section{Discussion}

Based on all the findings gathered on the challenges faced by both teachers and learners with Autism in their teaching and learner process, it is evident that they encounter struggles that need to be taken into consideration by related parties. Khowaja et al., (2019) in their research mentioned how the American Psychiatric Association defined autism spectrum disorder. According to them, Autism Spectrum Disorder (ASD) is a neurological disorder due to which diagnosed child may face difficulty in social communication or have a repeated or restricted set of behaviors. Buyuk et al., (2019) also believed that learners with Autism are mostly visual strategy learners and they tend to learn better through pictures and images. Previous studies have shown that social stories can improve understanding social situations, inferring perspectives of others and demonstrating appropriate behavior among learners with Autism. In conjunction to that, it is believed that a developed module that consists of social stories and images will help to increase learners with Autism's motivation and interest in the language learning process. Notbohm (2005) agreed that Autism is a highly complex disorder and learners with Autism indeed differ among them and each one of them behaves differently and prefers different things. In addition to that, another trait of children with Autism is that they learn through repetitions (Skewes et al., 2020).

\section{Conclusion and Implication}

As a global language, the importance and use of English language can no longer be denied. Both mainstream learners and learners with Autism can practice English language in their life in the long run. Education in today's world should involve everyone including special needs learners. Learners with Autism are believed to be able to get the same treatment and inclusion as mainstream learners. There has not been much spotlight given to both teachers who are involved with the learners with Autism and the learners with Autism themselves in trying to understand their ESL teaching and learning process. In the effort of bridging the gap and providing equality of education to both mainstream learners and learners with Autism, the very least thing is to get an insight of their world and find out of the challenges and obstacles in their ESL learning. The findings gathered from this paper can be helpful to provide related parties; policymakers, teachers and even parents to have an idea of what its like in the world of learners with Autism which then, helps them to be able to provide these learners with more opportunities to improve their learning journey. This research proposes to provide an insight into what learners with Autism and the teachers face in their journey of learning, also teaching English as a secondary language.

\section{About the Authors:}

Haida Umiera Hashim is a researcher at the Faculty of Education, Universiti Kebangsaan Malaysia. She earned her bachelor's degree and masters degree at the University of Malaya and Universiti Kebangsaan Malaysia (UKM) in the field of education (Teaching English as Secondary Language) respectively. She is currently pursuing her degree of philosophy (PhD) at the Universiti Kebangsaan Malaysia in the same area. ORCid ID : https://orcid.org/0000-00025710-3401 
Dr. Melor Md Yunus is an Associate Professor at the Faculty of Education, Universiti Kebangsaan Malaysia and is currently the Deputy Dean (Research and Innovation) at the Faculty of Education, Universiti Kebangsaan Malaysia (UKM). She holds a B.A. in English (Linguistics) from the University of Nevada-Reno, USA and an M.A. in TESL from the Arizona State University, USA. She then earned her Ph.D. in Education (TESL) from the University of Bristol, UK. Her areas of concentration are TESL, language pedagogy and the use of technology in TESL. Her expertise is in the area of Technology-enhanced Language Learning (TELL). ORCid ID : https://orcid.org/0000-0001-7504-7143

Dr. Helmi Norman is currently the Deputy Director of Instructional Technologies of the Center for Teaching and Curriculum Development, Universiti Kebangsaan Malaysia (UKM) and currently drives the e-learning transformation in the university. He is also a senior lecturer at the Faculty of Education, UKM. His research interests are in the field of digital learning and futuristic education. He was awarded as an Apple Distinguished Educator for driving transformation of national projects for primary, secondary, and higher education in promoting 1:1 pedagogical and learning approaches using the Apple ecosystem. He is a certified Professional Technologist of the Malaysian Board of Technologists. Dr Norman's global experience includes his appointment on the board of directors of the International Association for Blended Learning, which pioneers blended learning initiatives around the globe. He is also the pioneer of "dronagogy" in designing futuristic education with drone-based learning. ORCid ID : https://orcid.org/0000-0002-4717-3166

\section{References}

Adan, D. A., \& Hashim, H. (2021). Language Learning Strategies Used by Art School ESL Learners. Creative Education, 12(03), 653. https://doi.org/10.4236/ce.2021.123045.

American Psychiatric Association. (1996). Diagnostic and Statistical Manual of Mental Disorders (DSM-IV). Washington DC: American Psychiatric Association.

Bosseler, A., \& Massaro, D. W. (2003). Development and evaluation of a computer-animated tutor for vocabulary and language learning in children with Autism. Journal of Autism and developmental disorders, 33(6), 653-672. DOI: 0162-3257/03/1200-0653/0.

Busby, R., Ingram, R., Bowron, R., Oliver, J., \& Lyons, B. (2012). Teaching Elementary Children with Autism: Addressing Teacher Challenges and Preparation Needs. Rural educator, 33(2), 27-35.

Büyük, O. O., Nizam, A., Akgül, E. M., \& Çamurcu, A. Y. (2019). A Novel Money Teaching Method for Autism Spectrum Disorder Children Using Computer-Enhanced Techniques. Journal of Individual Differences in Education, 1(2), 80-88.

Chandran, G., \& Hashim, H. (2021). Self-Paced Formative Assessment: Concept and Applications in Learning ESL Vocabulary. Creative Education, 12(01), 140. https://doi.org/10.4236/ce.2021.121010.

Chu, S. Y., Mohd Normal, S. N. S. A. B., McConnell, G. E., Tan, J. S., \& Joginder Singh, S. K. D. (2020). Challenges faced by parents of children with autism spectrum disorder in Malaysia. Speech, Language and Hearing, 23(4), 221-231.DOI: 10.1080/2050571X.2018.1548678 
Dornyei, Z. (2019). Towards a better understanding of the L2 Learning Experience, the Cinderella of the L2 Motivational Self System. Studies in Second Language Learning and Teaching, 9(1), 19-30. http://dx.doi.org/10.14746/ssllt.2019.9.1.2.

Education Act 1996. 9.

Ghanouni, P.et al., (2019). Social stories for children with autism spectrum disorder: Validating the content of a virtual reality program. Journal of Autism and developmental disorders, 49(2), 660-668. https://doi.org/10.1007/s10803-018-3737-0.

Hannan, A., Satari, N. A., Abu, K., \& Yunus, F. (2020). The Challenge of Managing Children with Autism from Fathers' Perspectives. Humanities, 8(3), 367-379. DOI: 10.18488/journal.73.2020.83.367.379.

Happé, F., \& Frith, U. (2020). Annual Research Review: Looking back to look forward changes in the concept of Autism and implications for future research. Journal of Child Psychology and Psychiatry, 61(3), 218-232.

Kaprava, A. (2019). The importance of English in the modern world. In Інноваційні тенденції підготовки фахівців в умовах полікультурного та мультилінгвального глобалізованого світу. Київський національний університет технологій та дизайну. Innovative trends in training in a multicultural and multilingual globalized world. Kyiv National University of Technology and Design.

Khairuddin, K. F., Salleh, S. D., \& Amin, A. S. (2020). Supporting Students with Autism in Tertiary Education: Malaysian Lecturers' Views and Experiences. Universal Journal of Educational Research, 8(11A), 1-8.

Khowaja, K., Al-Thani, D., Banire, B., Salim, S. S., \& Shah, A. (2019, December). Use of augmented reality for social communication skills in children and adolescents with autism spectrum disorder (ASD): A systematic review. In 2019 IEEE 6th International Conference on Engineering Technologies and Applied Sciences (ICETAS) (pp. 1-7). IEEE.

Koo, S. H., Gaul, K., Rivera, S., Pan, T., \& Fong, D. (2018). Wearable Technology Design for Autism Spectrum Disorders. Archives of Design Research, 31(1), 3755.

Kravchenko, A., \& Kyzymenko, I. (2019). The Forth Industrial Revolution: new paradigm of society development or post-humanist Manifesto. Philosophy and Cosmology, (22), 120-128. https://doi.org/10.29202/phil-cosm/22/10.

Lord, C. et al., (2020). Autism spectrum disorder. Nature reviews Disease primers, 6(1), 1-23.

Luneski, A., Konstantinidis, E. I., Hitoglou-Antoniadou, M., \& Bamidis, P. D. (2008). Affective computer-aided learning for autistic children. In First Workshop on Child, Computer and Interaction.

Ministry of Education (MOE). (2013). National Education Blueprint (2013-2025). Putrajaya: Malaysian Ministry of Education.

Mokhtar, M., Yasin, M. H. M., \& Tahar, M. M. (2020). The Level of Knowledge and Skills of Special Education Teachers in Teaching with the Use of Learning Through Play Method. Jurnal Penelitian dan Pengembangan Pendidikan Luar Biasa, 6(2).

Notbohm, E., \& Zysk, V. (2006). Ten things your student with Autism wishes you knew. Arlington, Texas. Future Horizons.

Othman, M. F., \& Rahmat, N. E. (2020). The Effectiveness of Law Relating to Educational Right of Children with Disabilities in Malaysia. Environment-Behaviour Proceedings Journal, 5(15), 275-280. DOI: https://doi.org/10.21834/ebpj.v5i15.2484. 
Portes, J. R. M., Vieira, M. L., Souza, C. D. D., \& Kaszubowski, E. (2020). Parental styles and coparenting in families with children with Autism: cluster analysis of children's behavior. Estudos de Psicologia (Campinas), 37(1).

Porter, S. et al., (2017). Music therapy for children and adolescents with behavioural and emotional problems: A randomised controlled trial. Journal of Child Psychology and Psychiatry, 58(5), 586-594. Doi:10.1111/jcpp.12656.

Rahman, M. et al., (2020). A Review of Machine Learning Methods of Feature Selection and Classification for Autism Spectrum Disorder. Brain sciences, 10(12), 949. Doi:10.3390/brainsci10120949.

Ramakrishnan, R., Salleh, N. M., \& Alias, A. (2020). Technological Pedagogical and Content Knowledge Among Vocational Special Education Teachers. Religación, 4, 144-149.

Salleh, M. A. M. (2019). Inclusion of Children with Disabilities in General ECCE Centres. In $3 r d$ International Conference on Special Education (ICSE 2019). Atlantis Press.

Satari, N., Yasin, M. H. M., Toran, H., \& Mohamed, S. (2020). Application Reading Module for Children with Disabiliy among Students with Non-Verbal Autism. International Journal of Academic Research in Business and Social Sciences, 10(3). DOI:10.6007/IJARBSS/v10i3/7083

Shin, Y.C. et al., (2020). Challenges faced by parents of children with autism spectrum disorder in Malaysia. Speech, Language and Hearing, 23(4), 221-231, DOI: 10.1080/2050571X.2018.1548678

Skewes, J. C., Kemp, T., Paton, B., \& Hohwy, J. (2020). How are attention, learning, and social cognition related on the non-clinical autistic spectrum?. Acta Psychologica, 210, 103-157.

Symons, C., \& Ponzio, C. (2019). Schools cannot do it alone: a community-based approach to refugee youth's language development. Journal of Research in Childhood Education, 33(1), 98-118. https://doi.org/10.1080/02568543.2018.1531450.

Teo, J. X., Lau, B. T., \& Then, P. (2020). Autism Spectrum Disorders in Sarawak: An Overview and Analysis of Educator Awareness, Training, Development Opportunities, and Challenges. International Journal of Disability, Development and Education, 1-17.

UNESCO. Division for Inclusion, Peace and Sustainable Development, Education Sector. (2017). Education for sustainable development goals: Learning objectives. 